\title{
Acute inferior ST segment elevation myocardial infarction due to chemotherapy in a young man with testicular cancer
}

\section{Testis kanserli hastada kemoterapiye bağlı gelişen akut inferior ST segment elevasyonlu miyokard infarktüsü}

Veysel Tosun ${ }^{1}$, Necmettin Korucuk ${ }^{1}$, Murat Bayrak ${ }^{1}$, Mustafa Serkan Karakas ${ }^{1}$, Refik Emre Altekin ${ }^{1}$

${ }^{1}$ Akdeniz University Medical Faculty, Department of Cardiology, Antalya, Turkey

Corresponding author: Mustafa Serkan Karakas, Department of Cardiology, Akdeniz University Faculty of Medicine,

Dumlupinar Boulevard, Konyaalti, Antalya, Turkey.

E-mail: mserkan19@hotmail.com

Received/Accepted: November 30, 2015 / June 22, 2016

Conflict of interest: There is not a conflict of interest.

\section{SUMMARY}

Testicular cancer is the most common malignancy in men between 15 and 29 years of age. cisplatin, etoposide and bleomycin combination chemotherapy remains the mainstay of testicular cancer treatment. Acute myocardial infarction is a rare complication of these chemotherapeutics. In this case report, we present a case of 36-year-old male with acute inferior ST-segment elevation myocardial infarction after bleomycin injection. Because the patient had no significant risk factors for coronary artery disease, the infarction was likely caused by the chemotherapy regimen.

Keywords: Testicular Cancer, Acute Myocardial Infarction, Cisplatin, Bleomycin, Etoposide

ÖZET

Testis kanseri 15-29 yaş arasındaki erkeklerde en sık karşılaşılan kanserdir. Testis kanserinin tedavisinde sisplatin, etoposid ve bleomisin kombinasyonu ana tedavi rejimidir. Akut miyokard infarktüsü bu kemotörapotiklerin nadir bir komplikasyonudur. Bu yazıda bleomisin verilmesinden sonra akut inferior ST-segment elevasyonlu miyokard infarktüsü gelişen, koroner arter hastalığı için risk faktörü bulunmayan ve infarktüsün kemoterapiye bağlı olduğu düşünülen 36 yaşında erkek hasta sunulmuştur.

Anahtar sözcükler: Testis kanseri, Akut miyokard infarktüsü, Sisplatin, Bleomisin, Etoposid 


\section{INTRODUCTION}

Testicular cancer is a highly treatable, usually curable and the most common malignancy in men between 15 and 29 years of age ${ }^{1}$. Testicular cancer can be derived from any cell type found in the testicles. More than $95 \%$ of testicular cancers are germ cell tumors. Most of the remaining 5\% are sex cord-gonadal stromal tumours. Systematic randomised trials have shown that cisplatin, etoposide and bleomycin combination chemotherapy remains the mainstay of treatment ${ }^{2}$. With these chemotherapy some long term complications have now been recognised, including secondary leukaemia, therapy-related solid tumours, nephrotoxicity, neurotoxicity, pulmonary toxicity and infertility. ${ }^{3}$ Major complications on the vascular system are arterial occlusion, deep vein thrombosis, transient ischemic attack, stroke, angina pectoris, and acute myocardial infarction $^{3,4}$.

In the literature, cisplatin and bleomycin is thought to be the most likely agents causing myocardial infarction ${ }^{3,4}$. Also, myocardial infarction associated with these chemotherapeutics are very rare. We present a case of treatment-related acute myocardial infarction in a young man just after first course of chemotherapy for testicular mixed germ cell tumor.

\section{CASE REPORT}

A 36-year-old man was diagnosed the mixed germ cell tumor as a result of right orchiectomy biopsy, one month ago. The cancer had spread to lymph nodes in the pelvis and abdomen, so its stage was diagnosed as IIA. He received a combination of cisplatin $(35 \mathrm{mg})$ and etoposide $(175 \mathrm{mg})$ daily for five days. $\mathrm{He}$ had received bleomycin $(30 \mathrm{mg})$ on the second day. On the tenth day, he received second bleomycin $(30 \mathrm{mg})$ therapy and after one hour, he was consulted to cardiology department with sudden onset of chest pain. This was the first chest pain and he had no any other known disease as well any major cardiovascular risk factors. His blood pressure was 140/80 $\mathrm{mm} \mathrm{Hg}$ and the heart rate was 90 beats $/ \mathrm{min}$. There were no significant pathologic findings in the physical examination.

Electrocardiography demonstrated sinus rhythm and ST elevation in D2-D3 and aVF derivations, ST depression in D1aVL derivations (Figure 1). The bedside echocardiographic examination showed hypokinesia in inferior segments of the left ventricle. The global ejection fraction was normal. He was immediately taken to the catheter laboratory for coronary angiography, with the resulting diagnosis of acute inferior myocardial infarction. Left coronary angiography demonstrated normal left main coronary artery, normal left anterior descending artery (LAD) and normal circumflex coronary artery $(\mathrm{Cx})$. On the right coronary angiography, there was an intracoronary thrombotic lesion in the mid segment of the right coronary artery (RCA) (Figure 2A). A bare metal stent was implanted to RCA mid lesion (Figure 2B). The patient's medical treatment was revised, $100 \mathrm{mg}$ aspirin, 5 mg ramipril, $100 \mathrm{mg}$ metoprolol, $50 \mathrm{mg}$ isosorbide mononitrate, $40 \mathrm{mg}$ atorvastatin, $75 \mathrm{mg}$ clopidogrel, and $2 \times 0.6 \mathrm{~mL}$ enoxaparin were given as a daily medical treatment. During hospitalization in the coronary care unit, chest pain did not recur but on the fourth day, his blood count demonstrated a neutropenia (up to 190/mm3) and thrombocytopenia (up to $93000 / \mathrm{mm} 3$ ). Because of he had relapsing fever up to $39,5^{\circ} \mathrm{C}$, he was diagnosed with febrile neutropenia and started granulocyte colony stimulating factor (G-CSF) plus piperacillin-tazobactam antibiotherapy. He was transferred to the oncology clinic on the sixth day. He was discharged after recovering in the hospital and asymptomatic in the polyclinic control one month later. 


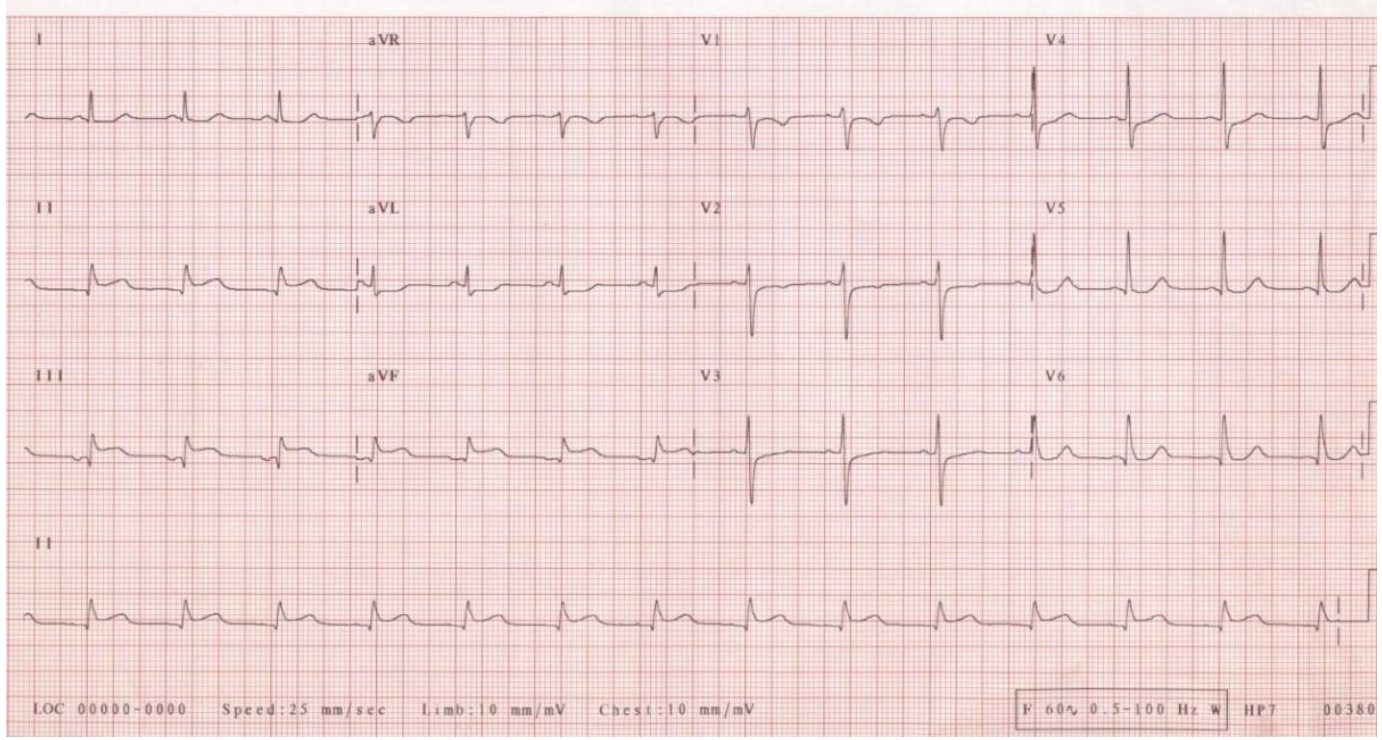

Figure 1: ST segment elevation in D2, D3 and aVF derivations, reciprocal ST segment depression in D1-aVL derivations on the electrocardiography.

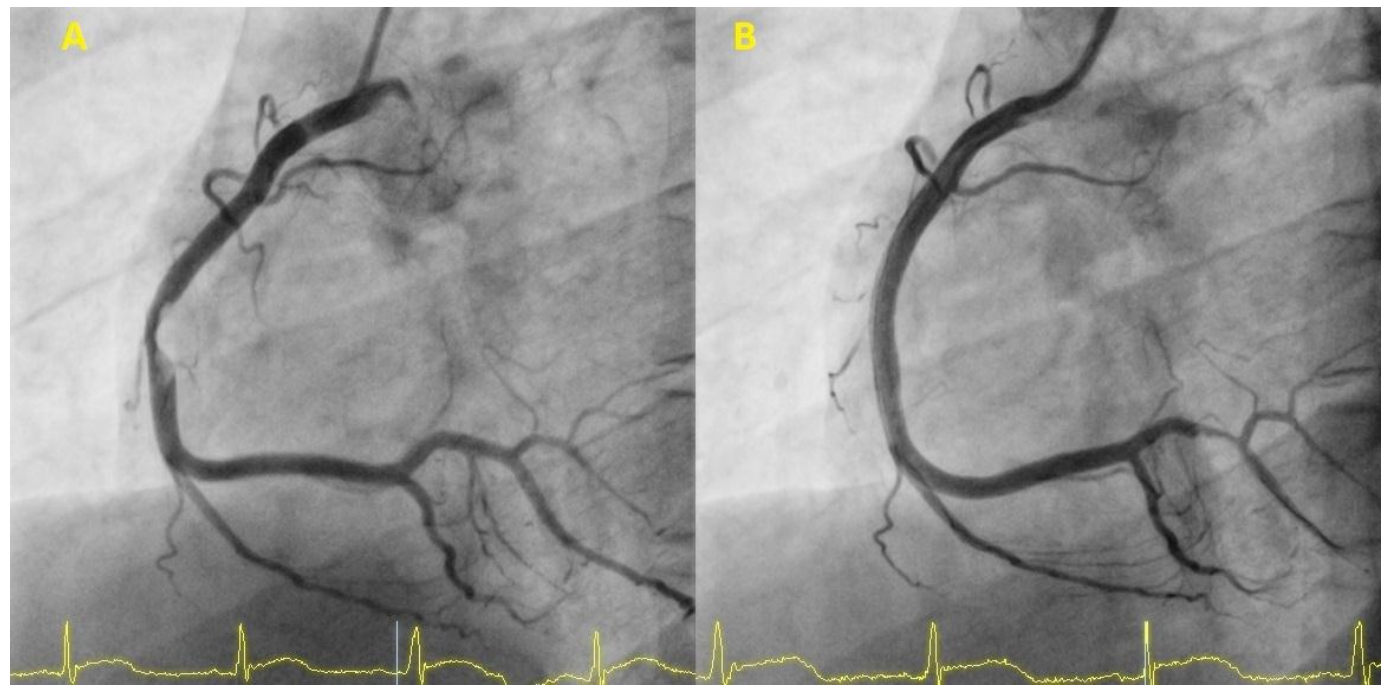

Figure 2: (A) Critical thrombotic lesion in RCA mid segment and (B) 100\% opening after stent implantation. 


\section{DISCUSSION}

Testicular cancer is the most common solid malignancy in young men ${ }^{1}$. It is only about $1 \%$ of all cancers in males and a highly treatable and usually curable cancer. More than $95 \%$ of testicular cancers are germ cell tumors. Germ cell tumors are broadly divided into seminomas and nonseminomas for treatment planning, because they have different prognostic and treatment algorithms. Seminomas are generally treated with surgical resection and continued with radiotherapy for early stage disease and chemotherapy for more advanced stage disease. In contrast, nonseminoma tumors are frequently treated with combined chemotherapy ${ }^{2}$. Basically, bleomycin, etoposide and cisplatin combination therapy has been the standard treatment for testicular metastatic cancers ${ }^{2}$. However, such combination chemotherapy causes some complications, including secondary leukemia, therapy related solid tumors, infertility, nephrotoxicity, neurotoxicity, and pulmonary and vascular toxicity ${ }^{3}$. Vascular toxicities include acute myocardial infarction, cerebrovascular events, deep vein thrombosis and Raynaud phenomenon.

Several case reports have been published about the myocardial infarction that seen in young patients after cisplatin and bleomycin therapy ${ }^{5,6}$. In some of the publications, the infarction had been developed only a few weeks or months after chemotherapy ${ }^{7,8}$, but the cases that infarction seen just after bleomycin first course chemotherapy are rare. Mermershtain et al reported an acute myocardial infarction patient 24 hours after the second bleomycin injection ${ }^{4}$. In our case, the myocardial infarction was developed about one hour after the second bleomycin injection.

Considering the cases in the literature, the majority of patients with myocardial infarction was observed in patients administered both cisplatin and bleomycin. We think the acute myocardial infarction in our case was probably caused by bleomycin, because myocardial infarction developed just after the bleomycin injection and five days after the cisplatin injection. But, further studies should be performed to determine which chemotherapeutics cause such thrombotic complications and other reasons.

The present patient did not have any cardiovascular risk factors or previous cardiovascular problems. Lesions of the coronary endothelium, clotting system disorders and coronary vasospasm induced by chemotherapeutics have been considered as possible causes of acute cardiovascular events. Special care should be given to these patients who have cardiovascular risk factors.

It should be noted that thrombocytopenia and febrile neutropenia may develop in such cases. Complete blood count should be monitored in these patients after myocardial infarction while taking antiplatelet therapy. Our patient platelets was decreased up to $93000 / \mathrm{mm} 3$, so we continued to dual antiplatelet therapy and did not see bleeding complications. Besides that, febrile neutropenia had developed in our patient and was treated by oncologists and infection specialists. $\mathrm{He}$ was asymptomatic and discharged after two weeks. Bleomycin did not added to cisplatin and etoposide by oncologists in the subsequent courses of chemotherapy.

\section{REFERENCES}

1. Aben KK, van Gaal C, van Gils NA, van der Graaf WT, Zielhuis GA. Cancer in adolescents and young adults (15-29 years): a populationbased study in the Netherlands 19892009. Acta Oncol 2012; 51: 922-33.

2. Pliarchopoulou K, Pectasides D. First-line chemotherapy of nonseminomatous germ cell tumors. Cancer Treat Rev 2009; 35: 563-69.

3. Chaudhary UB, Haldas JR. Longterm complications of chemotherapy for germ cell tumours. Drugs 2003; 63: 1565-77. 
4. Mermershtain W, Dudnik J, Gusakova I, Ariad S. Acute myocardial infarction in a young man receiving chemotherapy for testicular cancer: case report $\mathbf{J}$ Chemother 2001; 13: 658-60.

5. Bachmeyer C, Joly H, Jorest R. Early myocardial infarction during chemotherapy for testicular cancer. Tumori 2000; 86: 428-30.

6. Icli $\mathrm{F}$, Karaoguz $\mathrm{H}$, Dincol $\mathrm{D}$, Demirkazik A, Günel N, Karaoğuz $\mathrm{R}$, et al. Severe vascular toxicity associated with cisplatin-based chemotherapy. Cancer 1993; 72: 587-93.

7. Ozben B, Kurt R, Oflaz H, Sezer M, Basaran M, Goren T, et al. Acute anterior myocardial infarction after chemotherapy for testicular seminoma in a young patient. Clin Appl Thromb Hemost 2007; 13: 43942.

8. Ito D, Shiraishi J, Nakamura T, Maruyama N, Iwamura $\mathrm{Y}$, Hashimoto S, et al. Primary percutaneous coronary intervention and intravascular ultrasound imaging for coronary thrombosis after cisplatin-based chemotherapy. Heart Vessels 2012; 27: 634-8. 